\title{
Přechod mezi stupni základní školy: Od teoretického konceptu k možnostem facilitace ${ }^{1}$
}

\section{Transition from primary to lower secondary school: From a theoretical concept to the possibilities of facilitation}

\author{
Dominik Dvořák
}

\begin{abstract}
Abstrakt: Přechodu z prvního na druhý stupeň v rámci českého základního vzdělávání dosud nebyla věnována taková pozornost, jaké se dostává vstupu do základní školy nebo přechodu do vyššího sekundárního stupně často spojenému s volbou povolání. Jednou z prríčin může být, že žák v mnoha př́ípadech zůstává zdánlivě ve stejné organizaci a dokonce ve stejné budově. Přesto data ukazují, že přechod přináší nemalé části dětí značné obtíže. Náš výzkum se snaží identifikovat kurikulární faktory, které k těmto problémům mohou přispívat.
\end{abstract}

Klíčová slova: primární škola, nižší sekundární škola, přechod, Česká republika, kurikulum

\begin{abstract}
The transition from Czech primary school to lower secondary school has been studied much less than other transitions within the educational system. In many cases, the transition is not accompanied with the transfer - the pupil stays within one building and one organisation. Despite that, some pupils face serious difficulties after the transition. We look at the possible curricular factors that contribute to the post-transition problems.
\end{abstract}

Keywords: primary school, lower secondary school, transition, Czech republic, curriculum

\section{1 Úvod}

Základní osmi- či devítiletá škola se stala pro několik generací obyvatel České republiky natolik samozřejmou, že zapomínáme na relativní neobvyklost tohoto organizačního řešení. V zahraničí bývají primární a sekundární škola často oddělenými subjekty. Jejich časté propojení u nás $\mathrm{v}$ tzv. plně organizovaných základních školách zakrývá některé rozdíly mezi nimi a nevede automaticky k efektivní spolupráci mezi učiteli obou stupňů. Naše předchozí kvalitativní šetření (Dvořák et al., 2010) upozornilo na možnost malé připravenosti některých žáků přicházejících z prvního na druhý stupeň, jak ukazují vzpomínky devát’áků na nástup do šestého ročníku: „Začalo to být těžké.“ „To jsme se poprvé ztráceli.“

Naše kvalitativní zjištění jsou v souladu s kvantitativními daty školské statistiky, jež potvrzují dramatický nárůst počtu žáků opakujících ročník po přechodu na druhý stupeň (tabulka 1).

Zejména zohledníme-li rozdílné počty žáků $\mathrm{v}$ různých ročnících $\mathrm{v}$ důsledku charakteru demografické křivky, vidíme, že počet žáků opakujících ročník se v 6. ročníku zvýší více než trojnásobně oproti předchozímu ročníku a tento trend přetrvává i v následujících ročnících druhého stupně. Počet opakujících je dokonce vyšší než v 1. ročníku, kde se žák adaptuje na školu vůbec.

\footnotetext{
${ }^{1}$ Výzkum probíhá s finanční podporou MŠMT ČR v rámci projektu Centra základního výzkumu školního vzdělávání (LC06046).
} 
Tabulka 1

Počet a podíl opakujících žáků v základním vzdělávání podle ročníků (stav k 30. 9. 2009)

\begin{tabular}{|c|c|c|c|c|c|}
\hline Ročník & 1 & 2 & 3 & 4 & 5 \\
\hline $\begin{array}{c}\text { Počet } \\
\text { opakujících žáků }\end{array}$ & 1015 & 549 & 494 & 459 & 437 \\
\hline $\begin{array}{c}\text { Podíl opakujících } \\
\text { žáků (promile) }\end{array}$ & 10,7 & 6,0 & 5,4 & 5,0 & 4,8 \\
\hline Ročník & 6 & 7 & 8 & 9 & - \\
\hline $\begin{array}{c}\text { Počet } \\
\text { opakujících žáků }\end{array}$ & 1306 & 1219 & 1335 & 170 & - \\
\hline $\begin{array}{c}\text { Podíl opakujících } \\
\text { žáků (promile) }\end{array}$ & 15,9 & 14,7 & 15,9 & 2,0 & - \\
\hline
\end{tabular}

Zdroj: Statistická ročenka školství 2009/10 - Výkonové ukazatele. Tabulka C1.24.

\section{Pojmy a teorie}

V zahraniční literatuře je přechodu žáků mezi primární a nižší sekundární školou věnována poměrně značná pozornost, a to zejména tam, kde normativní přechod z jednoho typu instituce do jiného typu (tranzice) je obvykle doprovázen také změnou lokality (budovy, obce), kde je vykonávána školní docházka (přestup, transfer).

S přechodem jsou spojena jak negativní, tak pozitivní očekávání a určitá část žáků jej zvládne bez obtíží - Griebel a Berwangerová (2006) pro Německo uvádějí, že hladce tento vývojový milník absolvuje asi polovina dětí. Jiné děti však mohou mít celou řadu krátko- či dlouhodobých problémů.

V literatuře se nacházíme následující rozlišení vnímaných nebo skutečných problém spojených s přechodem na nový stupeň vzdělávání (Akos, Galassi, 2004):

- nové požadavky v oblasti učení (v anglické terminologii academic), kam lze zahrnout např. náročnost a množství učiva, případně souběh požadavků různých předmětů;

- vyšší organizační (procedurální) nároky - spojené např. se střídáním učitelů, přecházením mezi různými učebnami, př́padně s přechodem do jiné budovy, dojíždění do jiné obce;

- ovlišné sociální prostředí- např. soužití s novými spolužáky při přechodu do jiné školy, třídy, obavy z vyššího výskytu šikany, drog.

Zahraniční zkušenosti naznačují, že časté žákovské obavy spojené s přechodem z prvního stupně na druhý stupeň, jež se týkají vztahů s vrstevníky nebo odlišné organizace výuky na druhém stupni, se dětem daři poměrně rychle př́konat. Naproti tomu problémy spojené s kurikulem, vázané na obsahy vzdělávání mohou přetrvávat dlouhodobě. Povaha těchto problémů může být rozdílná - může jít např. o tzv. „nový start“", kdy učitelé druhého stupně považují dosavadní žákovou učení ve škole za nepříliš hodnotné, nenavazují na ně, začínají stavět svůj předmět „od nuly“. Na druhou stranu učitelé mohou př́edpokládat kontinuitu poznávání a pokračovat rychle k náročnějšímu abstraktnímu učivu, pro něž žáci z prvního stupně nemají dostatečně vytvořené předpoklady. $V$ obou př́padech to může vést $\mathrm{k}$ stagnaci či 
dokonce poklesu žákových znalostí a k problémům v oblasti postojů k učení (nuda ve škole, strach ze školy, pocity, že žák nezvládá nové požadavky).

Tyto diskrepance nemusí představovat problém obecně, ale může to zbrzdit či dokonce vykolejit žáky, pro něž je učivo určitého předmětu hodně náročné (Au, \& Taffy, 2011, s. 2). Také Wilhelm (2009) soudí, že žáci, kteří přicházejí na nižšśi sekundární úroveň s odpovídající úrovní čtenářské a matematické gramotnosti, vnitřní motivací nebo důsledným rodičovským dohledem nad školní prací, a s dostatečnou emoční vazbou ke škole (ke spolužákům, ke kroužkům nebo sportovním činnostem organizovaným školou apod.), mají dobrou šanci zvládnout podstatné složky kurikula sekundární školy. Tradičně byly školy nastaveny tak, aby dobře sloužily takovýmto dětem - dětem pocházejícími ze středostavovských vrstev majoritní společnosti. Ale dnes je snaha, aby uspěli všichni žáci, i ti, u nichž tyto předpoklady nejsou splněny. Diskontinuita kurikula tak představuje problém dotýkající se tedy i spravedlivosti, nejen kvality vzdělávání.

\section{Prvotní zjištění}

U nás jsou v současnosti $\mathrm{v}$ souvislosti $\mathrm{s}$ přechodem žáků na druhý stupeň často diskutovány zejména odchody žáků do víceletých gymnázií, tedy nástup vnější diferenciace. Méně váme o tom, jak dochází $\mathrm{k}$ přechodu žáků mezi dvěma institucemi či subkulturami v rámci jedné organizace (tranzici) tam, kde žák zdánlivě ,nikam neodchází“ a pokračuje ve školní docházce ve stejné základní škole, často ve stejné budově. U jiných žáků je navíc tranzice spojena $\mathrm{s}$ transferem do jiné školy $-\mathrm{k}$ přechodům žáků $\mathrm{z}$ neúplně organizovaných škol do větších škol a dále $\mathrm{k}$ redistribuci mezi jednotlivými základními školami (doplňující přijímací řízení do šestých ročníků škol s rozšířeným vyučováním některého předmětu apod.). Někdy nezvládnutý přechod na vyšší stupeň může vést $\mathrm{k}$ dalším transferům (např. žák má $\mathrm{v}$ průběhu prvního pololetí 6 . ročníku takové obtíže vzdělávací či sociální, že se rodiče rozhodnou pro přestup na jinou školu).

V praxi se věnuje pozornost problémům adaptace na nové sociální a organizační prostředí např. prostřednictvím adaptačních kurzů. Jak jsme naznačili, mohou však největší problémy ležet v oblasti vzdělávací (akademické).

Naše šetření se proto zaměřuje na analýzu a komparaci kurikulárních dokumentů. Zjišt'ujeme předběžně, že v posledních desetiletích u nás došlo $\mathrm{k}$ posunu v chápání vztahu primární a nižší sekundární školy.

Ani v dřive platných materiálech nebyla tranzici a transferu věnována velká pozornost. Pokud se zaměříme na stav bezprostředně předcházející roku 1989, zjištujeme, že Program výchovné práce (1983/1987, s. 212-213) věnoval návaznosti mezi preprimární a primární školou alespoň dvě stránky, avšak osnovy základní školy ze stejné doby přechodu na druhý stupeň věnují jen jeden odstavec:

První stupeň základní školy musí vytvářet předpoklady pro plynulý přechod žáků na 2. stupeň. Proto je velmi důležitá úzká spolupráce učitelů obou stupňů, která se uskutečňuje vzájemnými hospitacemi, konzultacemi, předáváním zkušeností i spoluprací metodických sdružení učitelů 1. stupně s předmětovými komisemi 2. stupně základní školy. Zejména ve 4. ročníku [vzhledem k tehdy čtyřleté primární škole - pozn. aut.] je potřebné, aby učitelé 1 . stupně postupně připravili žáky na styl práce na 2. stupni. Jde o to, aby žáci uměli pracovat $\mathrm{s}$ učebnicí a psát přiměřeně rychlým tempem, aby úkoly řešili samostatně a měli upevněny správné učební návyky. (Osnovy..., 1983, s. 9)

Je zajímavé si povšimnout, že se nijak netematizuje existence neúplně organizovaných základních škol, a tedy ani skutečnost přestupu/transferu žáků do jiných škol (k němuž ostatně docházelo i v průběhu prvního stupně, nebot' některé neúplné školy vyučovaly žáky jen 
v počátečních ročnících 1 . stupně, např. do 3. ročníku). Přesto byla akcentována důležitost př́ípravy na tranzici v průběhu posledních ročníků 1. stupně.

Naproti tomu v porevolučním koncepčním dokumentu zaznívají odlišné tóny:

Je nutné posilovat svébytnost a didaktickou specifičnost primární školy a zajistit, aby ji neohrožovaly např. požadavky na přijetí do vyššího stupně školy, jednostranně orientované jen na výkon nebo jen na znalosti požadované osnovami vyučovacích předmětů. (České vzdělání a Evropa, 1999, s. 59)

Primární vzdělávání má vytvářet základ pro všechno pozdější učení, formovat vztah ke vzdělání vůbec a kompenzovat nerovnosti vyplývající z rozdílné sociální a kulturní úrovně rodin, $\mathrm{z}$ nichž děti přicházejí, což je ve shodě s pojetím tohoto stupně vzdělávání ve světě. Současně se v jinak úsporně formulovaném dokumentu ještě jednou opakuje: „Pro primární vzdělávání bychom měli koncipovat samostatný vzdělávací program, orientovaný př́mo na kultivaci a osobnostní rozvoj dítěte, a nikoli hlavně na přípravu žákủ pro druhý stupeň.“ (ibid., s. 60) Stejně to učitelům prezenují média: „Je rozhodně nezdravé, aby obsah vzdělávání nižšího stupně byl diktován požadavky stupně vyššího.“ (Hrubá, 2002, s. 2)

Zdá se to být ambivalentní - škola má, a současně nemá připravovat žáky pro navazující studium. Jedním $\mathrm{z}$ vysvětlení by mohla být nevíra $\mathrm{v}$ to, že požadavky 2 . stupně jsou legitimní a odrážejí „správné“ pojetí vzdělávání.

Při analýze obecné úrovně cílů vzdělávání tedy pozorujeme zásadní přehodnocení role primární školy ve vztahu ke škole sekundární. Vnucuje se tak otázka, zda výše uvedené obtíže žáků při tranzici, projevující se mj. skokovým nárůstem opakování ročníků, nejsou do značné míry „naprogramované“ v současných strukturálních a kurikulárních charakteristikách vzdělávacího systému.

\section{Závěr - otázky pro další výzkum}

Uvedené citáty odrážejí stav na nejobecnější rovině existence kurikula, která bývá označována jako rovina ideální (Thijs, van den Akker, 2009) nebo koncepční (Průcha, 2002). V dalších krocích budeme sledovat, jak se tato pojetí promítají do operacionalizace cílů a obsahů kurikula na nižší rovině konkrétnějších českých kurikulárních projektů (rámcové vzdělávací programy) až do úrovně jednotlivých vzdělávacích oborů, resp. školních předmětů. V odborné literatuře se v této souvislosti mluví o kontinuitě kurikula jako facilitujícím faktoru z hlediska tranzice žáků na vyšší stupeň vzdělávání. Proto se zaměříme i na přesnější analýzu věcných kritérií pro evaluaci kurikula z tohoto zorného úhlu a na odpovídající terminologii. Současně se pokusíme o využití rozvíjené metodologie pro komparaci českého kurikulárního rámce a zahraničních kurikul zejména z hlediska řešení návaznosti obou ročníků.

\section{Literatura}

Akos, P., \& Gallasi, J. P. (2004). Middle and high school transitions as viewed by students, parents, and teachers. Professional School Counselling, 7(4), 212-221.

Au, K. H., \& Taffy, R. E. (2011). The staircase curriculum: Whole-school collaboration to improve literacy achievement. New England Reading Association Journal, 46(2), 1-8.

České vzdělání a Evropa. Strategie rozvoje lidských zdrojů při vstupu do Evropské unie. (1999). Praha: Sdružení pro vzdělávací politiku.

Dvořák, D., Starý, K., Urbánek, P., Chvál, M., \& Walterová, E. (2010). Česká základní škola. Viceprípadová studie. Praha: Karolinum.

Griebel, W., \& Berwanger, D. (2006). Transition from primary school to seconadary school in Germany. International Journal of Transitions in Childhood, 2, 32-39. 
Hrubá, J. (2002). Kdo zjedná nápravu? Zpráva ČŠI o školním roce 2000/2001. Učitelské listy, 9(6), 24.

Program výchovné práce pro jesle a mateřské školy. (1984). Praha: SPN.

Průcha, J. (2002). Moderni pedagogika. Praha: Portál.

Statistická ročenka školství 2009/10 - Výkonové ukazatele. Dostupné z www.uiv.cz

Thijs, A., van den Akker, J. (Eds.). (2009). Curriculum in development. Enschede: SLO.

Učebni osnovy pro 1.-4. ročník základní školy. (1983). Praha: SPN.

Wilhelm, T. (2009). Structural and cultural shifts to change the status quo. Leadership, 38(4), 22-27.

\section{Kontakt}

RNDr. Dominik Dvořák

Univerzita Karlova v Praze

Pedagogická fakulta, Ústav výzkumu a rozvoje vzdělávání

Myslíkova 7, 11000 Praha 1

e-mail: dominik.dvorak@pedf.cuni.cz

\section{Bibliografické údaje}

Dvořák, D. (2011). Přechod mezi stupni základní školy: Od teoretického konceptu k možnostem facilitace. In T. Janík, P. Knecht, \& S. Šebestová (Eds.), Smišený design v pedagogickém výzkumu: Sbornik přispèvkĩ z 19. výročni konference České asociace pedagogického výzkumu (s. 57-61). Brno: Masarykova univerzita.

Dostupné z: http://www.ped.muni.cz/capv2011/sbornikprispevku/dominikdvorak.pdf doi: 10.5817/PdF.P210-CAPV-2012-7 